\title{
A Clinical Study on Role of Shigru Root Kwath in Mutrashmari
}

\section{Research Article}

\section{Binod Kalita ${ }^{*}$}

1. Assistant Professor, Department of Shalya Tanta,

Government Ayurvedic College \& Hospital, Jalukbari, Guwahati-781014, Assam

\begin{abstract}
The clinical study was done in 60 cases of urolithiasis in randomized controlled pattern to evaluate the efficacy of Shigru (Moringa oleifera Lam) root decoction in medical management of urinary stone (Mutrashmari). The study was conducted at Department of Shalya Tantra, Government Ayurvedic College and Hospital, Nanded, Maharashtra. For assessment of result patients were investigated by USG \& X-ray KUB. Clinical features like pain, burning micturition, haematuria and strangury were also used for analysis of result. Patient's routine blood and urine examination were carried out. The study reveals that Shigru root decoction has significant role in the management of mild to moderate sized urolithiasis and also give immediate relief to associated features.
\end{abstract}

Keywords : Mutrashmari, Shigru, Decoction, Haematuria, Strangury, Yavakut churna (Minute pieces)

\section{Introduction}

Mutrashmari (Urolithiasis) is a clinical entity, which has been included under eight dreaded diseases (Asta Maharoga) by Acharya Sushruta(1) and Vagbhatta(2). The only rational treatment for this condition is surgical removal or lithotripsy of the stone, even the smaller stone which are left untreated in a hope of expulsion doesn't get expelled always rather they increase in size. $(3,4)$ Even in present advanced era, repeated surgeries are inevitable for many patients due to recurrences of the disease. Medical management of urolithiasis is still a challenge to medical field.

In Ayurveda various modalities of treatment has been mentioned. Sushruta had described both medical and surgical management of mutrashmari. $(5,6)$ Sushruta, Charaka and Vagbhatta had mentioned use of Shigru in various form for treatment of mutrashmari. $(7,8,9,10)$

Numbers of drug have been tried to treat urolithiasis in different centers all over India with varying results.

The objective of this study was to establish and reassess the effect of Shigru root kwath in mutrashmari. The study was carried out irrespective of dosha involvement and type of urinary calculus.

\section{Materials and methods}

Patients of 5 years to 65 years of age group having calculus without severe obstructive uropathy were selected.

Detail histories of patient were recorded and informed consents were taken. Clinical examinations,

*Corresponding Author:

\section{Binod Kalita}

Assistant Professor, Department of Shalya Tanta, Government Ayurvedic College \& Hospital,

Jalukbari, Guwahati-781014, Assam

E-mail: drbinodkalita75@gmail.com radiological and pathological investigations were done before, during and after treatment and the data were recorded meticulously in case record from.

\section{Selection criteria of patients}

Patients of 5 years to 65 years of age group.

Patients of both sexes.

Patients having calculus of size not more than $20 \mathrm{~mm}$ $\mathrm{x} 20 \mathrm{~mm}$.

\section{Rejection criteria of patients}

Patients with uncontrolled diabetes mellitus.

Patients with malignant hypertension.

Patients with hormonal imbalance.

Patients with severe renal function impairment.

Patients with severe obstructive uropathy.

Carcinoma within the urinary tract.

\section{Materials \\ Root of Shigru}

The extracted root of shigru was made yavakut churna in the Rasashala of Govt. Ayurved College and Hospital, Nanded. Sachets containing $20 \mathrm{gms}$ of shigru root churna were prepared.

\section{Preparation of Shigru root kwath}

To prepare kwath, 20gms of Shigru root yavakut churna is boiled in $320 \mathrm{ml}$ of water till $1 / 8$ th part of water, i.e. $40 \mathrm{ml}$ remains. Then $k$ wath is filtered. Patients were advised to take the kwath in lukewarm condition. In patients aged below 15 years doses were reduced to half.(11)

\section{Standard of the drug}

To evaluate the standard of the drug Shigru root $k w a t h$, used for the study, following test were carried out in drug testing laboratory of Govt. Ayurved College, Nanded and the values have been shown against them.

Specific gravity -1.0174 
Relative viscosity -1.9285

$\mathrm{pH}-6.25$

Bitterness (dilution method) $-1500 \mathrm{ml}$ distilled water required to make $100 \mathrm{ml}$ Shigru root kwath tasteless.

\section{Method}

The work has been designed for documenting the evaluation of effect of Shigru root kwath in mutrashmari and the study was conducted dividing the patients in two groups.

\section{Experimental Group (Group - A)}

A total of 30 patients were selected randomly for study under this group and patients were given Shigru root kwath $40 \mathrm{ml}$ twice daily in lukewarm condition showing the procedure of preparation of kwath. And the patients were give 29 sachet containing 20gms of Shigru root churna and asked to report after 15 days and in between if any complication arises. Thus the treatment was continued for 90 days. The clinical, radiological and pathological findings were recorded after each 30 days.

\section{Control Group (Group-B)}

Another 30 patients were selected randomly and were given one empty capsule twice daily with one glass of water.

Patients of both groups were advised to take plenty of water orally and to avoid spinach, brinjal, tomato, chickoo, cashewnut, amla, pumpkin, excessive milk and milk product etc.

\section{Statistical Analysis:}

To assess the result of the study, both objective and subjective findings were meticulously recorded before, during and after completion of treatment. The most leading clinical features of urolithiasis were taken as subjective parameter for analysis. They are pain, burning micturition, haematuria and strangury. Findings of ultrasonography in terms of size and site calculus were recorded before and after treatment and were used for analysis of result.

\section{Grading pattern used for assessment of subjective and objective parameters:}

The criteria adopted to assess the result were in the manner stated below and were regarded to all patients.

\section{Pain:}

- Severe (3+): Pain was graded as severe, when patient complained of pain even after taking medicines.

- Moderate (2+): Pain was graded as moderate when patient complained of pain tolerable after taking medicine.

- Mild (1+): Pain was graded as mild when patient could tolerate without taking any medicine.

- No Pain (0): In quiescent calculus the pain was grades as ' 0 '.

\section{Burning Micturition:}

- Severe (3+): If patient complained of severe burning micturition it was graded as severe $(3+)$.

- Moderate (2+): In case of tolerable burning micturition gradation was moderate $(2+)$.

- Mild (1+): In case of very less burning micturition gradation was mild (1+).

- No Burning Micturition (0): If no burning micturition complained of, gradation was $(0)$.

\section{Haematuria:}

- Severe (3+): If patients voided reddish urine, gradation was $(3+)$.

- Moderate (2+): If patients voided smoky urine, gradation was $(2+)$.

- Mild (1+): If R.B.C. detected only in microscope gradation was $(1+)$.

- No Haematuria (0): If no R.B.C. detected in microscope gradation was (0).

Strangury:

- Severe

- Moderate $(2+)$

- Mild (1+)

- No Strangury (0)

\section{Ultrasonography:}

The findings of ultrasonography were given prime importance. The size and site of calculi were meticulously recorded before starting treatment and compared with post treatment findings. And the findings were considered as positive if -

1. Calculus is evacuated,

2. Calculus stationary for prolonged period moved down the urinary tract and

3. Size of calculus becomes smaller.

As the sample size was small, students ' $t$ ' test was applied to know the significance of subjective parameter converting them into quantitative data.

To analyze the differences of size and site of calculus before and after treatment, ' $z$ ' test was applied as the numbers of calculi were more than thirty in each group. The multiple calculi of same patients were regarded as individual calculus. $0.05)$.

The level of significance was set at $5 \%$. ( $\mathrm{p}=$

Table no. 1: Table showing the mean () and standard deviation (S.D.) of pain of both experimental (A) and control (B) group on each follow up.

\begin{tabular}{|l|l|l|l|l|l|}
\hline \multirow{2}{*}{$\begin{array}{c}\text { Sl. } \\
\text { No. }\end{array}$} & \multirow{2}{*}{ Day } & \multicolumn{2}{|c|}{ Group A } & \multicolumn{2}{c|}{ Group B } \\
\cline { 3 - 6 } & & $\begin{array}{c}\text { Mean } \\
(\bar{x})\end{array}$ & S.D. & Mean (x) & S.D. \\
\hline 1. & 0 & 2.63 & 0.49 & 2.6 & 0.67 \\
\hline 2. & 30 & 1.67 & 0.55 & 2.37 & 0.61 \\
\hline 3. & 60 & 0.83 & 0.69 & 2.2 & 0.71 \\
\hline 4. & 90 & 0.53 & 0.68 & 2.53 & 0.62 \\
\hline
\end{tabular}


Table no. 2: Table showing the mean $(\bar{x})$ and standard deviation (S.D.) of burning micturition of both experimental (A) and control (B) group on each follow up.

\begin{tabular}{|c|c|c|c|c|c|}
\hline \multirow{2}{*}{$\begin{array}{l}\text { Sl. } \\
\text { No. }\end{array}$} & \multirow[t]{2}{*}{ Day } & \multicolumn{2}{|c|}{ Group A } & Group B & \\
\hline & & $\begin{array}{c}\text { Mean } \\
(\bar{x})\end{array}$ & S.D. & $\operatorname{Mean}(\bar{x})$ & S.D. \\
\hline 1. & 0 & 2.67 & 0.48 & 2.3 & 0.91 \\
\hline 2. & 30 & 1.60 & 0.62 & 2.2 & 0.76 \\
\hline 3. & 60 & 0.73 & 0.63 & 2.33 & 0.88 \\
\hline 4. & 90 & 0.30 & 0.59 & 2.4 & 0.92 \\
\hline
\end{tabular}

Table no. 3: Table showing the mean $(\bar{x})$ and standard deviation (S.D.) of haematuria of both experimental (A) and control (B) group on each follow up.

\begin{tabular}{|l|l|l|l|l|l|}
\hline \multirow{2}{*}{$\begin{array}{c}\text { Sl. } \\
\text { No. }\end{array}$} & \multirow{2}{*}{ Day } & \multicolumn{2}{|c|}{ Group A } & \multicolumn{2}{c|}{ Group B } \\
\cline { 3 - 6 } & & $\begin{array}{c}\text { Mean } \\
(\boldsymbol{x})\end{array}$ & S.D. & $\begin{array}{c}\text { Mean } \\
(\boldsymbol{x})\end{array}$ & S.D. \\
\hline 1. & 0 & 0.43 & 0.89 & 1.1 & 0.82 \\
\hline 2. & 30 & 0.47 & 0.57 & 0.73 & .0 .73 \\
\hline 3. & 60 & 0.40 & 0.67 & 0.6 & 0.77 \\
\hline 4. & 90 & 0.17 & 0.46 & 0.93 & 0.69 \\
\hline
\end{tabular}

Table no. 4: Table showing the mean $(\bar{x})$ and standard deviation (S.D.) of strangury of both experimental (A) and control (B) group on each follow up.

\begin{tabular}{|l|l|l|l|l|l|}
\hline SI. & Day & \multicolumn{2}{c|}{ Group A } & \multicolumn{2}{c|}{ Group B } \\
\cline { 3 - 6 } No. & & $\begin{array}{c}\text { Mean } \\
(\boldsymbol{x})\end{array}$ & S.D. & $\begin{array}{c}\text { Mean } \\
(\boldsymbol{x})\end{array}$ & S.D. \\
\hline 1. & 0 & 0.08 & 0.99 & 0.06 & 0.77 \\
\hline 2. & 30 & 0.33 & 0.60 & 0.05 & 0.57 \\
\hline 3. & 60 & 0.13 & 0.34 & 0.05 & 0.62 \\
\hline 4. & 90 & 0.13 & 0.34 & 0.47 & 0.68 \\
\hline
\end{tabular}

Graph No. 1: Linear graph No. 1 showing the mean of different symptoms at $0,30,60$ and $90^{\text {th }}$ day of treatment in group $\mathrm{A}$

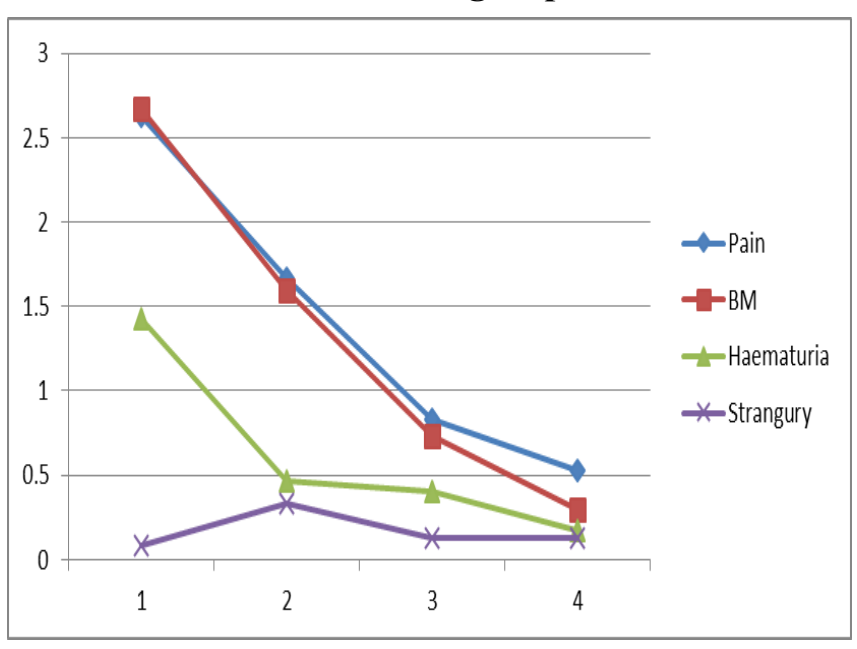

Graph No. 2: Linear graph No. 2 showing the mean of different symptoms at $0,30,60$ and $90^{\text {th }}$ day of treatment in group $B$

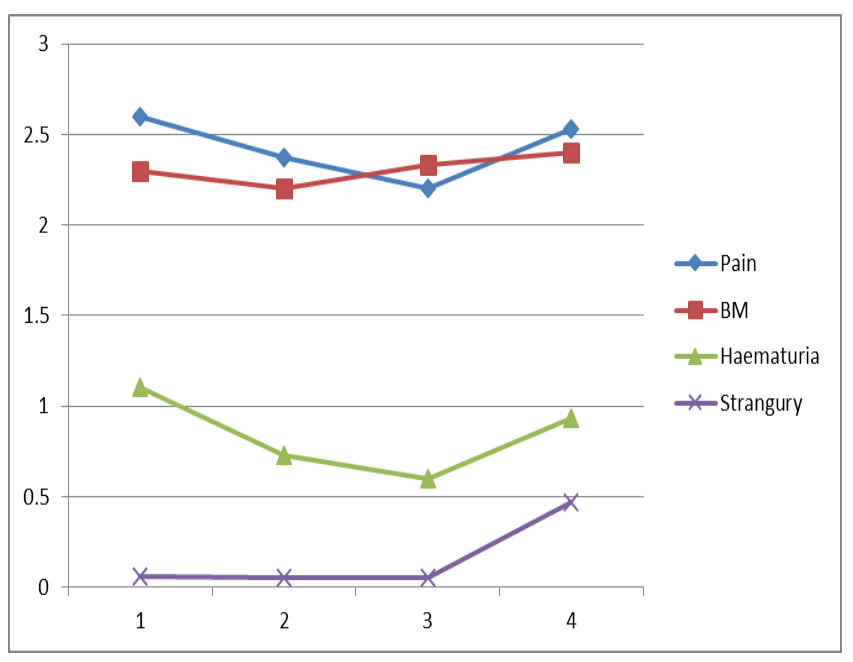

Table no. 5.1: Table showing the mean $(\vec{x})$ and standard deviation (S.D.), standard error (S.E.) and ' $t$ ' value of differences of pain between different follow up of group $A$.

\begin{tabular}{|l|l|l|l|l|l|l|}
\hline SI. No. & Follow up & \multicolumn{1}{|c|}{$\overline{\boldsymbol{x}}$} & \multicolumn{1}{|c|}{ S.D. } & \multicolumn{1}{|c|}{ S.E. } & \multicolumn{1}{|c|}{ 't' } & \multicolumn{1}{|c|}{} \\
\hline 1. & $00-30^{\text {th }}$ day & 0.97 & 0.49 & 0.09 & 10.89 & $\mathrm{p}<0.05$ \\
\hline 2. & $30-60^{\text {th }}$ day & 0.83 & 0.59 & 0.11 & 07.68 & $\mathrm{p}<0.05$ \\
\hline 3. & $60-90^{\text {th }}$ day & 0.43 & 0.50 & 0.09 & 04.77 & $\mathrm{p}<0.05$ \\
\hline 4. & $00-90^{\text {th }}$ day & 2.10 & 0.80 & 0.14 & 14.38 & $\mathrm{p}<0.05$ \\
\hline
\end{tabular}


Table no. 5.2: Table showing the mean $(\bar{x})$ and standard deviation (S.D.), standard error (S.E.) and ' $t$ ' value of differences of pain between different follow up of group $B$.

\begin{tabular}{|l|l|l|l|l|l|l|}
\hline \multicolumn{1}{|c|}{ Sl. No. } & \multicolumn{1}{|c|}{ Follow up } & \multicolumn{1}{|c|}{ S } & \multicolumn{1}{|c|}{ S.D. } & \multicolumn{1}{c|}{ S.E. } & \multicolumn{1}{c|}{ 't' } & \multicolumn{1}{c|}{$\mathbf{p}$} \\
\hline 1. & $00-30^{\text {th }}$ day & 0.23 & 0.67 & 0.122 & 1.88 & $\mathrm{p}>0.05$ \\
\hline 2. & $30-60^{\text {th }}$ day & 0.17 & 0.71 & 0.130 & 1.30 & $\mathrm{p}>0.05$ \\
\hline 3. & $60-90^{\text {th }}$ day & 0.36 & 0.62 & 0.113 & 3.18 & $\mathrm{p}>0.05$ \\
\hline 4. & $00-90^{\text {th }}$ day & 0.03 & 0.59 & 0.107 & 0.28 & $\mathrm{p}>0.05$ \\
\hline
\end{tabular}

The statistical analysis shown in table number 5.1 and 5.2 suggest that in group A the effect of treatment on pain is significant at each follow up and also after completion of treatment. In group B the difference in pain is not significant except $60-90^{\text {th }}$ day of treatment.

Hence the difference observed in group $\mathrm{A}$ is due to the effect of the drug.

Table no. 6.1: Table showing (x), S.D., S.E. and ' $t$ ' value of differences of burning micturition between different follow up of group A.

\begin{tabular}{|l|l|l|l|l|l|l|}
\hline \multicolumn{1}{|c|}{ Sl. No. } & \multicolumn{1}{|c|}{ Follow up } & \multicolumn{1}{c|}{$\overline{\boldsymbol{x}}$} & \multicolumn{1}{|c|}{ S.D. } & \multicolumn{1}{c|}{ S.E. } & \multicolumn{1}{c|}{ 't' } & \multicolumn{1}{c|}{$\mathbf{p}$} \\
\hline 1. & $00-30^{\text {th }}$ day & 1.07 & 0.52 & $0, .095$ & 11.26 & $\mathrm{p}<0.05$ \\
\hline 2. & $30-60^{\text {th }}$ day & 0.86 & 0.62 & 0.113 & 7.61 & $\mathrm{p}<0.05$ \\
\hline 3. & $60-90^{\text {th }}$ day & 0.43 & 0.56 & 0.102 & 4.21 & $\mathrm{p}<0.05$ \\
\hline 4. & $00-90^{\text {th }}$ day & 2.36 & 0.66 & 0.120 & 19.6 & $\mathrm{p}<0.05$ \\
\hline
\end{tabular}

Table no. 6.2: Table showing (x), S.D., S.E. and ' $t$ ' value of differences of burning micturition between different follow up of group $B$.

\begin{tabular}{|l|l|l|l|l|l|l|}
\hline \multicolumn{1}{|c|}{ Sl. No. } & \multicolumn{1}{|c|}{ Follow up } & \multicolumn{1}{|c|}{$\overline{\boldsymbol{x}}$} & \multicolumn{1}{|c|}{ S.D. } & \multicolumn{1}{c|}{ S.E. } & \multicolumn{1}{c|}{ 't' } & \multicolumn{1}{c|}{$\mathbf{p}$} \\
\hline 1. & $00-30^{\text {th }}$ day & 0.17 & 0.57 & 0.104 & 1.63 & $\mathrm{p}>0.05$ \\
\hline 2. & $30-60^{\text {th }}$ day & 0.13 & 0.65 & 0.118 & 1.10 & $\mathrm{p}>0.05$ \\
\hline 3. & $60-90^{\text {th }}$ day & 0.07 & 0.78 & 0.142 & 0.492 & $\mathrm{p}>0.05$ \\
\hline 4. & $00-90^{\text {th }}$ day & 0.10 & 0.79 & 0.144 & 0.694 & $\mathrm{p}>0.05$ \\
\hline
\end{tabular}

The statistical analysis shown in table number 6.1 and 6.2 suggest that in group A the effect of treatment of burning micturition is significant at each follow up and also after completion of treatment. In group B the difference in B.M. is not significant. Hence the difference observed in group A is due to the effect of the drug.

Table no. 7.1: Table showing $(\bar{x})$, S.D., S.E. and ' $t$ ' value of differences of haematuria between different follow up of group A.

\begin{tabular}{|l|l|l|l|l|l|l|}
\hline \multicolumn{1}{|c|}{ Sl. No. } & \multicolumn{1}{c|}{ Follow up } & \multicolumn{1}{c|}{$\overline{\boldsymbol{x}}$} & \multicolumn{1}{|c|}{ S.D. } & \multicolumn{1}{c|}{ S.E. } & \multicolumn{1}{c|}{ 't' } & \multicolumn{1}{c|}{$\mathbf{p}$} \\
\hline 1. & $00-30^{\text {th }}$ day & 1 & 0.69 & 0.1296 & 7.93 & $\mathrm{p}<0.05$ \\
\hline 2. & $30-60^{\text {th }}$ day & 0.03 & 0.47 & 0.085 & 0.352 & $\mathrm{p}>0.05$ \\
\hline 3. & $60-90^{\text {th }}$ day & 0.23 & 0.42 & 0.076 & 3.02 & $\mathrm{p}<0.05$ \\
\hline 4. & $00-90^{\text {th }}$ day & 1.26 & 0.89 & 0.162 & 7.77 & $\mathrm{p}>0.05$ \\
\hline
\end{tabular}

Table no. 7.2: Table showing $(\bar{x})$, S.D., S.E. and ' $t$ ' value of differences haematuria between different follow up of group $B$.

\begin{tabular}{|l|l|l|l|l|l|l|}
\hline \multicolumn{1}{|c|}{ Sl. No. } & \multicolumn{1}{|c|}{ Follow up } & \multicolumn{1}{c|}{$\overline{\boldsymbol{x}}$} & \multicolumn{1}{|c|}{ S.D. } & \multicolumn{1}{c|}{ S.E. } & \multicolumn{1}{c|}{ 't' } & \multicolumn{1}{c|}{$\mathbf{p}$} \\
\hline 1. & $00-30^{\text {th }}$ day & 0.17 & 0.52 & 0.095 & 1.79 & $\mathrm{p}>0.05$ \\
\hline 2. & $30-60^{\text {th }}$ day & 0.30 & 0.82 & 0.149 & 2.01 & $\mathrm{p}>0.05$ \\
\hline 3. & $60-90^{\text {th }}$ day & 0.26 & 0.58 & 0.106 & 2.45 & $\mathrm{p}<0.05$ \\
\hline 4. & $00-90^{\text {th }}$ day & 0.16 & 0.43 & 0.08 & 2.0 & $\mathrm{p}>0.05$ \\
\hline
\end{tabular}


The statistical analysis shown in table number 7.1 and 7.2 suggest that in group A the effect of treatment on haematuria is significant at each follow up except $30-60^{\text {th }}$ day of treatment. In group B the difference in haematuria is not significant except in the period of 60 to $90^{\text {th }}$ day where the increase in haematuria was significant.

Hence the difference observed in group $\mathrm{A}$ is due to the effect of the drug.

Table no. 8.1: Table showing the mean $(\bar{x})$ and standard deviation (S.D.), standard error (S.E.) and ' $t$ ' value of differences of strangury between different follow up of group $A$.

\begin{tabular}{|l|l|l|l|l|l|l|}
\hline Sl. No. & \multicolumn{1}{|c|}{ Follow up } & \multicolumn{1}{|c|}{$\overline{\boldsymbol{x}}$} & \multicolumn{1}{|c|}{ S.D. } & \multicolumn{1}{c|}{ S.E. } & \multicolumn{1}{c|}{ 't' } & \multicolumn{1}{c|}{$\mathbf{p}$} \\
\hline 1. & $00-30^{\text {th }}$ day & 0.47 & 0.50 & 0.091 & 5.16 & $\mathrm{p}<0.05$ \\
\hline 2. & $30-60^{\text {th }}$ day & 0.20 & 0.40 & 0.073 & 2.73 & $\mathrm{p}<0.05$ \\
\hline 3. & $60-90^{\text {th }}$ day & 0.00 & - & - & - & $\mathrm{p}>0.05$ \\
\hline 4. & $00-90^{\text {th }}$ day & 0.67 & 0.80 & 0.146 & 4.58 & $\mathrm{p}<0.05$ \\
\hline
\end{tabular}

Table no. 8.2: Table showing the mean $(\bar{x})$ and standard deviation (S.D.), standard error (S.E.) and ' $t$ ' value of differences of strangury between different follow up of Group - B.

\begin{tabular}{|l|l|l|l|l|l|l|}
\hline Sl. No. & \multicolumn{1}{|c|}{ Follow up } & \multicolumn{1}{c|}{$\overline{\boldsymbol{x}}$} & \multicolumn{1}{|c|}{ S.D. } & \multicolumn{1}{|c|}{ S.E. } & \multicolumn{1}{|c|}{ 't' } & \multicolumn{1}{c|}{ ' } \\
\hline 1. & $00-30^{\text {th }}$ day & 0.10 & 0.38 & 0.069 & 1.44 & $\mathrm{p}>0.05$ \\
\hline 2. & $30-60^{\text {th }}$ day & 0.07 & 0.49 & 0.089 & 0.786 & $\mathrm{p}>0.05$ \\
\hline 3. & $60-90^{\text {th }}$ day & 0.10 & 0.61 & 0.111 & 0.90 & $\mathrm{p}>0.05$ \\
\hline
\end{tabular}

The statistical analysis shown in table number 8.1 and 8.2 suggest that in group A the effect of treatment on strangury is significant at each follow up except in the period of 60 to $90^{\text {th }}$ day where no difference was observed and also after completion of treatment. In group B the difference in strangury is not significant.

Hence the difference observed in group $\mathrm{A}$ is due to the effect of the drug.

Graph No. 3: Liner graph No. 3 showing difference of mean in different duration of Treatment in Group A

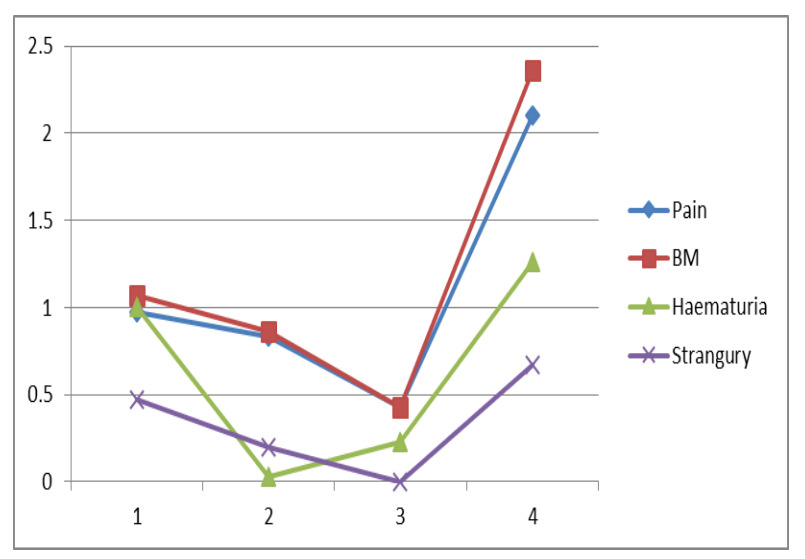

Graph No. 4: Liner graph No. 4 showing difference of mean in different duration of Treatment in Group B

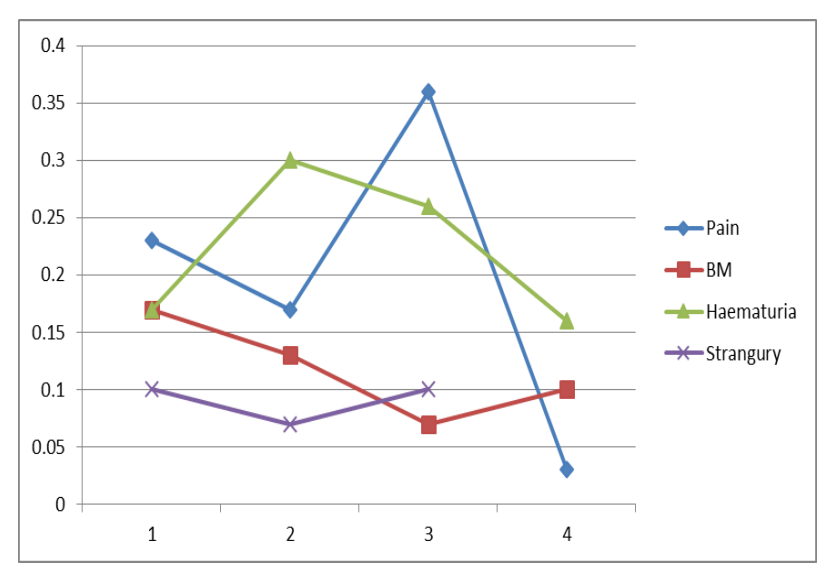

Table no. 9: Table showing the value of mean ( $\bar{x}$, standard deviation (S.D.) of group A and B and their standard error (S.E.) and with ' $Z$ ' value of differences in sizes of stones in $\mathrm{mm}$ after treatment.

\begin{tabular}{|c|c|c|c|c|c|c|}
\hline \multicolumn{2}{|c|}{ Group A } & \multicolumn{2}{c|}{ Group B } & \multirow{2}{*}{ S.E. } & Z \\
\cline { 1 - 3 } Mean & S.D. & Mean & S.D. & & \\
\hline 5.33 & 4.14 & 0.57 & 0.50 & 0.636 & 7.484 & $\mathrm{p}<0.05$ \\
\hline
\end{tabular}

To evaluate the significance of differences in sizes of calculi observed between group A and B, ' $Z$ ' test was applied as the number of calculi were more than 30 in both groups.

The statistical analysis shown in the table no. 9 suggest that the differences in sizes of calculi between group A and group B is significant. The mean differences in the size of the calculi is more in group A. So the differences observed in sizes of calculi were due to the effect of the drug used in group A, not occurring by chance. 
Table no 10: Number of patients showing effect of treatment in terms of cured, improved and not cured on the basis of U.S.G. findings (Group A)

\begin{tabular}{|c|c|c|c|}
\hline $\begin{array}{c}\text { Sl. } \\
\text { No. }\end{array}$ & Result & $\begin{array}{c}\text { No. of } \\
\text { Patients }\end{array}$ & Percentage \\
\hline 1. & Cured & 13 & $43.33 \%$ \\
\hline 2. & Improved & 16 & $53.33 \%$ \\
\hline 3. & Not cured & 01 & $03.34 \%$ \\
\hline & Total & 30 & $100.00 \%$ \\
\hline
\end{tabular}

As shown in table no 10 , out of 30 patients studied under experimental group, 13 patients got complete relief, whereas in 16 patients, sizes of stones became smaller and or moved down the urinary tract. In only one case no any change in size or site of calculus was noted.

The number of patients cured and improved were more and the result is significant statistically $(\mathrm{p}<0.05)$.

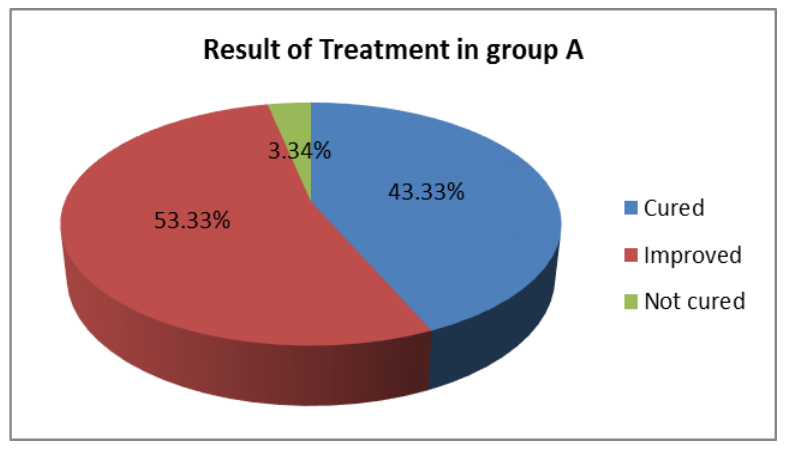

Table No. 11: Table showing relief of pain after treatment in experimental group

\begin{tabular}{|c|c|c|c|}
\hline $\begin{array}{c}\text { Sl. } \\
\text { No. }\end{array}$ & Result & $\begin{array}{c}\text { No. of } \\
\text { Patients }\end{array}$ & Percentage \\
\hline 1. & Complete relief & 17 & $56.67 \%$ \\
\hline 2. & Partial relief & 12 & $40.00 \%$ \\
\hline 3. & No relief & 01 & $03.33 \%$ \\
\hline & Total & 30 & $100 \%$ \\
\hline
\end{tabular}

$\mathrm{c}^{2}=13.4 ; \mathrm{p}<0.05$

As shown in table no. 11, out of 30 patients studied under experimental group, 17 patients got complete relief of pain, 12 patients got partial relief and one patient didn't get relief of pain. The findings are found significant statistically $(\mathrm{p}<0.05)$.

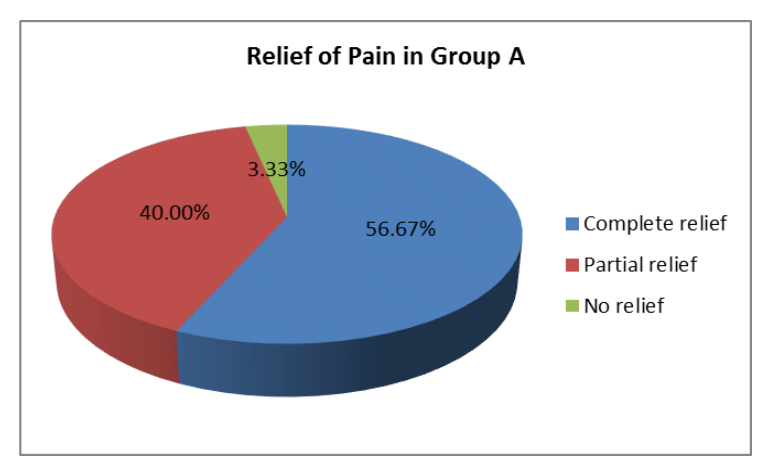

Table no. 12: Table showing relief of burning micturition after treatment in experimental group.

\begin{tabular}{|c|c|c|c|}
\hline $\begin{array}{c}\text { Sl. } \\
\text { No. }\end{array}$ & Result & $\begin{array}{c}\text { No. of } \\
\text { patients }\end{array}$ & Percentage \\
\hline 1. & Complete relief & 23 & $76.67 \%$ \\
\hline 2. & Partial relief & 07 & $23.33 \%$ \\
\hline 3. & No relief & 00 & $00.00 \%$ \\
\hline & Total & 30 & $100 \%$ \\
\hline
\end{tabular}

As shown in table no. 12, out of 30 patients studied under experimental group, 23 patients got complete relief and 7 patients got partial relief of burning micturition. $(\mathrm{p}<0.05)$.

The findings are found significant statistically

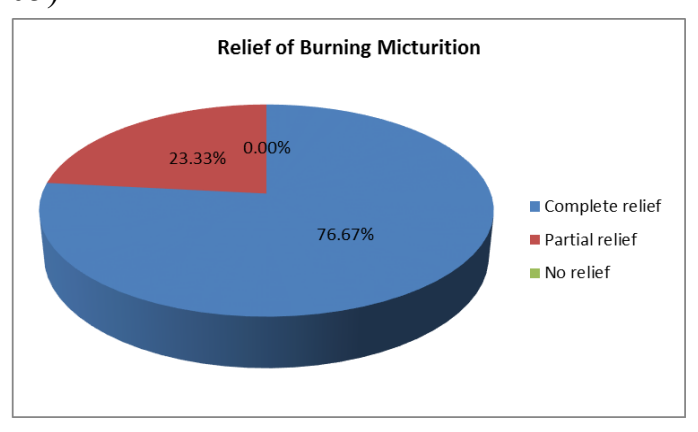

Table no. 13: Table showing relief of haematuria after treatment in experimental group.

\begin{tabular}{|c|c|c|c|}
\hline $\begin{array}{c}\text { Sl. } \\
\text { No. }\end{array}$ & Result & $\begin{array}{c}\text { No. of } \\
\text { Patients }\end{array}$ & Percentage \\
\hline 1. & Complete relief & 21 & $84 \%$ \\
\hline 2. & Partial relief & 02 & $08 \%$ \\
\hline 3. & No relief & 02 & $08 \%$ \\
\hline & Total & 25 & $100 \%$ \\
\hline
\end{tabular}

$$
\mathrm{c}^{2}=28.87 ; \mathrm{p}<0.05
$$

As shown in table no. 13, out of 25 patients studied under experimental group, 21 patients got complete relief, 2 patients got partial relief and 2 patients didn't get relief of haematuria.

The findings are found significant statistically $(\mathrm{p}<0.05)$.

Table no. 14: Table showing relief of strangury after treatment in experimental group.

\begin{tabular}{|c|c|c|c|}
\hline $\begin{array}{c}\text { Sl. } \\
\text { No. }\end{array}$ & Result & $\begin{array}{c}\text { No. of } \\
\text { patients }\end{array}$ & Percentage \\
\hline 1. & Complete relief & 11 & $78.5 \%$ \\
\hline 2. & Partial relief & 03 & $21.5 \%$ \\
\hline 3. & No. relief & 00 & $00 \%$ \\
\hline & \multicolumn{4}{|c|}{ Total } & 14 & $100 \%$ \\
\hline \multicolumn{4}{|c|}{$\mathrm{c}^{2}=13.87 ; \mathrm{p}<0.05$} \\
\hline
\end{tabular}

As shown in table no. 14, out of 14 patients studied under experimental group, 11 patients got complete relief and 3 patients got partial relief of strangury. 
The findings are found significant statistically $(\mathrm{p}<0.05)$.

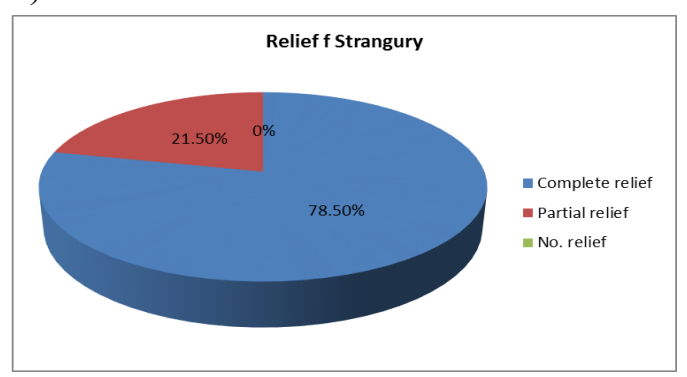

Table no 15: Table showing the opinion of patients about the modality of treatment (Group A)

\begin{tabular}{|c|c|c|c|c|c|}
\hline $\begin{array}{c}\text { SI. } \\
\text { No. }\end{array}$ & Opinion & $\begin{array}{c}\text { No. of } \\
\text { Pa- } \\
\text { tients }\end{array}$ & $\begin{array}{c}\text { Per- } \\
\text { centage }\end{array}$ & $\mathbf{c}^{2}$ & $\mathbf{p}$ \\
\hline 1. & Good & 16 & 53.33 & & \\
\hline 2. & Satisfactory & 11 & 36.67 & 8.6 & $\begin{array}{c}\mathrm{p}< \\
0.05\end{array}$ \\
\hline 3. & $\begin{array}{c}\text { Not Satis- } \\
\text { factory }\end{array}$ & 03 & 10.00 & & \\
\hline & Total & 30 & 100 & & \\
\hline
\end{tabular}

The table shows that the difference in the number of three opinion was significant. The number of patients giving the opinion as the modality of treatment is good were more and it is significant statistically.

In group B not a single opinion stating good or satisfactory was found.

\section{Discussion}

The clinical study was conducted at Government Ayurved College, Nanded, Maharashtra.

For the clinical study special case paper was prepared.

Patients having calculus in urinary tract, diagnosed by X-ray K.U.B. and U.S.G. were selected for the study.

Essential investigations including routine blood examination, blood urea, serum creatinine, urine routine examination etc. were carried out.

Yavakut churna of shigru root was prepared in Rasashala of Government Ayurved College, Nanded for preparation of kwath.

Drug was tested to know its standard.

Along with drug patients were advised to take plenty of fluid and to avoid harmful diets.

Patients were treated in O.P.D. levels, not hampering other routine work.

Patients were checked clinically, laboratorically and radiologically at necessary intervals.

No any complication was seen. Patients under group B were consistent with presenting features and were advised surgical intervention at the end.

The obtained data were analysed with statistical methods separately.

Patients could not be followed up for long term to rule out any incidence of recurrences due to short period of study.

The modality of treatment was less time consuming, economical, non-invasive and very easy. The opinion of the patients about the modality of treatment were recorded and statistically analysed.

\section{Conclusion}

From the study it is concluded that the internal use of Shigru root kwath for a period of 60-90 day is very effective in Mutrashmari (urinary calculi) and can overcome the challenge to the medical management of mutrashmari and only by taking plenty fluid and avoiding harmful diet mutrashmari can't be cured.

\section{References}

1. Yadavji Trikamji Acharya (Editor), Sushruta Samhita of Sushruta with Nibandha Samgraha commentary of Sri Dalhanacharya, Edition 1994, Choukhamba Surbharti Prakashan, Varanasi, page no. 120.

2. Gupta Atridev (Editor), Astanga Hridayam of Vagbhatta, $14^{\text {th }}$ Edition, 2003, Choukhamba Sanskrit Sangsthan, Varanasi, page no. 249.

3. R.C.G. Russell, Norman S. Williams and Christopher J.K. Bulstrode (Editors), Bailey and Love's Short Practice of Surgery, 24 ${ }^{\text {th }}$ Edition, 2004 Edward Arnold (Publishers) Ltd., London, page no. 1350.

4. Hugh Dudley W. Scott MC., Dougal and David C Carter, Rob and Smith's Operative Urology, $4^{\text {th }}$ Edition, Butter Worth's, page no. 54-82.

5. Yadavji Trikamji Acharya (Editor), Sushruta Samhita of Sushruta with Nibandha Samgraha commentary of Sri Dalhanacharya, Edition 1994, Choukhamba Surbharti Prakashan, Varanasi, page no. 347.

6. Yadavji Trikamji Acharya (Editor), Sushruta Samhita of Sushruta with Nibandha Samgraha commentary of Sri Dalhanacharya, Edition 1994, Choukhamba Surbharti Prakashan, Varanasi, page no. 349.

7. Shashtri Kashinath and Chaturbedi (Editor), Charak Samhita of Agnibesh revised by Charaka and Drihabala, Vol. 2, reprint 1998, Choukhamba Bharati Academy, Varanasi, page no. 730.

8. Yadavji Trikamji Acharya (Editor), Sushruta Samhita of Sushruta with Nibandha Samgraha commentary of Sri Dalhanacharya, Edition 1994, Choukhamba Surbharti Prakashan, Varanasi, page no. 348 .

9. Gupta Atridev (Editor), Astanga Hridayam of Vagbhatta, $14^{\text {th }}$ Edition, 2003, Choukhamba Sanskrit Sangsthan, Varanasi, page no. 369.

10.Shastri Ambikadutta, Bhaisajya Ratnavali, $18^{\text {th }}$ Edition 2005, Choukhamba Sanskrit Sansthan, page no. 712 .

11.Tripathi Brahmananda, Sharangadhara Samhita of Pandit Sharangadhara, $3^{\text {rd }}$ Edition 1998, Choukhamba Surabharati Prakashan, Varanasi, pae no. 133 . 